\title{
POTENSI BAKTERI PEREDUKSI SULFAT TERHADAP TERHADAP PERUBAHAN KADAR SULFAT TERLARUT MEDIA TUMBUH
}

\author{
Asmarlaili Sahar Hanafiah, A. Rauf, Mazlina \\ Program Studi Pascasarjana Pertanian USU Medan 20155 \\ Corresponding author : assahar@gmail.com
}

\begin{abstract}
ABSTRAK
Keterbatasan lahan subur untuk pertanian mendorong peneliti untuk menggali potensi lahan sulfat masam bagi pengembangan pertanian. Tanah sulfat masam mempunyai luas yang cukup potensial untuk di manfaat kan sebagai lahan pertanian, namun tanah ini mempunyai berbagai masalah dan kendala dalam pengembangannya. Tanah sulfat masam mempunyai $\mathrm{pH}$ rendah dengan ketersediaan unsur hara yang rendah dan kelarutan $\mathrm{Al}$ dan besi yang tinggi. Disamping itu lahan sulfat masam mengandung pirit yang apabila teroksidasi akan menyebabkan terjadinya penurunan $\mathrm{pH}$ hingga $<3.5$. Diperlukan suatu teknologi agar tanah sulfat masam bisa dimanfaatkan untuk pengembangan pertanian Bakteri pereduksi sulfat mempunyai kemampuan untuk mereduksi sulfat di alam sehingga kadar sulfat tanah menurun. Tujuan penelitian ini untuk mengisolasi bakteri pereduksi sulfat dari lahan sulfat masam dan dari sumber sulfat lainnya dan selanjutnya melakukan uji potensi bakteri tersebut di laboratorium. Hasil penelitian ini menunjukkan bahwa dari tiga sumber isolat yaitu tanah sulfat masam, limbah pabrik kertas dan air panas sumber belerang, diperoleh beberapa isolat bakteri pereduksi sulfat yang diberi nama sesuai dengan asalnya yaitu TSM (tanah sulfat masam), LK (limbah pabrik kertas) dan AP (Air panas mengandung belerang). Hasil pengujian yang dilakukan pada media posgate cair dengan berbagai perlakuan kemasaman $(\mathrm{pH})$ menunjukkan bahwa pemberian BPS menurunkan kadar sulfat media tumbuh.
\end{abstract}

Keywords: tanah sulfat masam, kompos, BPS, sulfat

\section{PENDAHULUAN}

Lahan sulfat masam di Indonesia luasnya mencapai 6,71 juta ha yang tersebar di pulau Kalimantan, Sumatera. Lahan sulfat masam dijumpai di wilayah yang mempunyai topografi termasuk datar $(<3 \%)$. Dilihat dari luasan, topografi dan ketersediaan air maka keberadaan lahan sulfat masam mulai diperhatikan untuk pengembangan lahan pertanian terutama dengan semakin berkurangnya lahan subur untuk pertanian. Lahan tersebut mempunyai potensi untuk pengembangan tanaman pangan dan tahunan. Sebagian lahan tersebut telah dibuka untuk transmigrasi dan ditanami padi, palawija dan buah2an dengan hasil yang umumnya di bawah potensi produksi tanaman (Nugroho et al, 1992).

Kendala agronomi yg dihadapi di tanah sulfat masam adalah pengaruh langsung kemasaman terutama akibat meningkatnya kelarutan/keracunan $\mathrm{Al} \&$ besi (III), Mn dan ion $\mathrm{H}$, kahat fosfat karena difiksasi oleh $\mathrm{Fe} \& \mathrm{Al}$ membentuk Fe-P \& Al-P, kejenuhan basa rendah dan kahat hara, salinitas. Apabila kondisi tergenang dijumpai masalah keracunan besi (II), keracunan $\mathrm{H} 2 \mathrm{~S}$, keracunan $\mathrm{CO} 2$ \& asam2 organik. Sedangkan kendala fisik tanah yaitu hambatan perkembangan akar pada horizon sulfat karena cekaman kahat air untuk tanaman, (Dent, 1986). 
Pertanian di lahan sulfat masam memerlukan masukan teknologi baru agar produksi yang dihasilkan cukup baik serta kelestarian lingkungannya dapat terjaga dengan baik dan tidak terjadi degradasi lahan. Aplikasi BPS dapat menurunkan konsentrasi sulfat di dalam tanah, memperbaiki sifat kimia tanah, yang ditunjukkan adanya perubahan $\mathrm{pH}, \mathrm{C}$ organik (Siagian dkk.,2015, Widyati, 2007). Pemberian bahan organik sebagai sumber elektron yang diikuti dengan penggenangan untuk memutus suplai oksigen sebagai akseptor elektron akan merangsang aktivitas BPS (Widyati, 2007; Doshi, 2006). Hasil penelitian Siagian dkk. (2015) menunjukkan bahwa pemberian BPS menurun kandungan sulfat tanah bekas tambang batubara serta meningkatkan pertumbuhan tanaman karet di polibeg setelah satu bulan perlakuan isolat BPS.

Dari hasil penelitian Martha Sinjak dan Asmarlaili Sahar Hanafiah (2016) diperoleh 20 isolat BPS yang berasal dari tiga sumber yaitu dari tanah sulfat masam Kuala Simpang, sumber air panas belerang Lau Sidebuk-debuk kab Tanah Karo, dan dari limbah fabrik kertas PT Toba Pulp Lestari Porsea. Hasil penelitian tersebut menunjukkan bahwa BPS yang diuji pada berbagai $\mathrm{pH}$ media tumbuh (postgate cair) mampu meningkatkan $\mathrm{pH}$ media tumbuh tersebut. Diperlukan penelitian lebih lanjut untuk mengetahui potensi BPS terhadap kadar sulfat terlarut media tumbuh

\section{BAHAN DAN METODE}

Uji Potensi BPS pada Media Posgate Cair terhadap Kelarutan Sulfat

Isolat isolate BPS yang akan diuji, dibiakkan dalam media postge cair dengan berbagai $\mathrm{pH}$ yaitu 5,$5 ; 5,00 ; 4,5 ; 4,0 ; 3,5 ; 3,0$ dan $\mathrm{pH} 2,5$. Rancangan penelitian yang digunakan adalah RAL nonfaktorial dengan menggunakan 20 isolat BPS dan dua ulangan. Percobaan ini dilakukan di laboratorium Biologi Tanah FPUSU. Media yang sudah diisolasi dengan perlakuan BPS diinkubasi selama 14 hari. Setelah inkubasi diamati perubahan warna pada media tumbuh. Jika media menjadi hitam menunjukkan adanya aktifitas BPS . Selanjutnya dilakukan analisa kadar sulfat terlarut di dalam media pertumbuhan tersebut dengan metoda turbidimetri dengan alat ukur spectrophotometer.

\section{Hasil Penelitian}

Hasilnya pengamatan kadar sulfat terlarut tertera pada Tabel 1 di bawah ini.

Tabel 1. Kadar Sulfat dalam Larutan pada Berbagai Tingkat pH Setelah 14 hari inkubasi

\begin{tabular}{llllllll}
\hline Kode & \multicolumn{6}{l}{ Kadar Sulfat (ppm) } \\
\cline { 2 - 8 } Isolat & pH 5.5 & pH 5 & pH 4.5 & pH 4 & pH 3.5 & pH 3 & pH 2.5 \\
\hline AP 1 & 41.44 abcd & $32.81 \mathrm{ab}$ & 101.28 & $130.16 \mathrm{fg}$ & 130.78 & $140.97 \mathrm{cde}$ & 151.00 \\
AP 3 & $47.78 \mathrm{abcd}$ & $39.59 \mathrm{ab}$ & 113.44 & $113.16 \mathrm{bcdef}$ & 133.56 & $144.03 \mathrm{cde}$ & 156.00 \\
AP 4 & $113.50 \mathrm{e}$ & $43.94 \mathrm{ab}$ & 53.59 & $107.5 \mathrm{bcdef}$ & $\mathbf{1 1 4 . 9 4}$ & $136.44 \mathrm{bcd}$ & 154.03 \\
AP 6 & $49.97 \mathrm{abcd}$ & $29.28 \mathrm{ab}$ & 120.28 & $128.91 \mathrm{efg}$ & 123.94 & $146.75 \mathrm{cde}$ & 151.25 \\
AP 7 & $43.03 \mathrm{abcd}$ & $23.19 \mathrm{ab}$ & 84.22 & $120.72 \mathrm{cdefg}$ & 135.66 & $157.28 \mathrm{de}$ & 145.31 \\
AP 8 & $43.78 \mathrm{abcd}$ & $44.25 \mathrm{ab}$ & 54.78 & $131.81 \mathrm{fg}$ & 145.00 & $159.63 \mathrm{de}$ & 152.94 \\
AP 9 & 77.69 d & $32.97 \mathrm{ab}$ & 89.38 & $147.28 \mathrm{~g}$ & 134.16 & $143.09 \mathrm{cde}$ & 157.88 \\
AP 10 & $122.06 \mathrm{e}$ & $90.34 \mathrm{~cd}$ & 115.53 & $126.25 \mathrm{efg}$ & 127.22 & $158.75 \mathrm{de}$ & 157.94 \\
LK 1 & 66.56 cd & $21.28 \mathrm{ab}$ & $\mathbf{3 6 . 2 5}$ & $\mathbf{7 7 . 6 5} \mathbf{a}$ & 132.44 & $156.31 \mathrm{de}$ & 155.88 \\
LK 2 & $22.38 \mathrm{a}$ & $24.34 \mathrm{ab}$ & 82.72 & $93.63 \mathrm{abc}$ & 134.97 & $156.44 \mathrm{de}$ & 137.03 \\
LK 3 & $25.56 \mathrm{ab}$ & $13.34 \mathrm{a}$ & $\mathbf{2 8 . 9 1}$ & $96.94 \mathrm{abcd}$ & $\mathbf{1 2 0 . 0 0}$ & $149.28 \mathrm{de}$ & 148.56 \\
LK 4 & $30.03 \mathrm{abc}$ & $50.44 \mathrm{ab}$ & $\mathbf{4 1 . 1 9}$ & $\mathbf{8 6 . 1 3} \mathbf{~ a b}$ & $\mathbf{1 1 4 . 2 5}$ & $138.25 \mathrm{cde}$ & $\mathbf{1 1 8 . 1 6}$ \\
\hline
\end{tabular}




\begin{tabular}{llllllll}
\hline LK 6 & $144.22 \mathrm{abcd}$ & $95.31 \mathrm{~cd}$ & 51.56 & $\mathbf{8 8 . 6 2} \mathbf{~ a b}$ & 134.84 & $\mathbf{1 0 7 . 8 1} \mathbf{a}$ & 143.66 \\
LK 7 & 63.41 bcd & $30.06 \mathrm{ab}$ & 56.59 & $110.06 \mathrm{bcdef}$ & 150.72 & $123.72 \mathrm{abc}$ & $\mathbf{1 0 3 . 0 9}$ \\
TSM 1 & $23.56 \mathrm{ab}$ & $24.19 \mathrm{ab}$ & 140.97 & $127.47 \mathrm{efg}$ & 124.47 & $160.44 \mathrm{e}$ & 153.91 \\
TSM 2 & $72.00 \mathrm{~d}$ & $94.59 \mathrm{~cd}$ & 140.16 & $125.44 \mathrm{efg}$ & 135.31 & $155.31 \mathrm{de}$ & 152.13 \\
TSM 3 & $68.59 \mathrm{~cd}$ & $46.41 \mathrm{ab}$ & 89.38 & $102.03 \mathrm{abcde}$ & 132.16 & $158.34 \mathrm{de}$ & 152.41 \\
TSM 4 & $127.63 \mathrm{e}$ & $29.16 \mathrm{ab}$ & 68.81 & $122.91 \mathrm{defg}$ & 148.13 & $\mathbf{1 1 6 . 0 3} \mathbf{~ a b}$ & 134.22 \\
TSM 5 & $43.09 \mathrm{abcd}$ & $58.72 \mathrm{bc}$ & 99.72 & $123.63 \mathrm{defg}$ & 132.38 & $139.65 \mathrm{cde}$ & $\mathbf{1 1 1 . 8 4}$ \\
TSM 6 & $119.84 \mathrm{e}$ & $108.97 \mathrm{~d}$ & 113.56 & $125.31 \mathrm{efg}$ & 149.09 & $144.16 \mathrm{cde}$ & 137.47 \\
\hline
\end{tabular}

Ket : Angka yang diikuti dengan huruf yang sama menunjukkan tidak berbeda nyata pada taraf 5\% menurut uji rata Duncan

Hasil pengamatan pada Tabel 1 menunjukkan bahwa pada media tumbuh yang mempunyai $\mathrm{pH} 2,5$ yang ditumbuhi oleh LK7, TSM5, LK4 mengandung sulfat terlarut paling rendah, sedangkan pada media tumbuh dengan $\mathrm{pH} 3,0$ isolat LK6 dan TSM 4 yang mempunyai kemampuan mereduksi sulfat paling tinggi. Untuk media tumbuh dengan $\mathrm{pH} 3,5$ isolate LK4, AP4, LK3 mempunyai kemampuan mereduksi sulfat yang tertinggi, ini ditunjukkkan oleh kadar sulfat terlarut yang lebih rendah. Pada $\mathrm{pH}$ 4,0 isolat isolate LK1, LK4, LK6 yang lebih berperan dalam mereduksi sulfat.

\section{DAFTAR PUSTAKA}

Castro, H.F., N.H. Williams, A. Ogram. 2000. Phylogeny of Sulfat Reducing Bacteria. Microbiol Ecology. 31: 1-9

Dent,D. 1986. Acid sulphate soils: A basleine for research and development. Publication No. 39 ILRI, Wageningen, The Netherlands.

Doshi, S.M. 2006. Bioremediation of Acid Mine Drainage Using Sulfate Reducing Bacteria. National Network of Environmental Management Studies Fellow. www.epa.gov

Nugroho,K., Alkasuma, Paidi, W. Wahdini, Abdurachman, $\mathrm{H}$. Suhardjo, dan IPG. Widjaja-Adhi. 1992. Peta areal potensial untuk pengembangan pertanian lahan

\section{SIMPULAN}

Dari sumber air panas belerang, limbah pabrik kertas dan tanah sulfat masam berhasil direduksi bakteri pereduksi sulfat (BPS) dengan kode berturut turut AP, LK dan TSM.

Hasil pengujian di media cair menunjukkan inokulasi BPS menurunkan kadar sulfat di dalam media tumbuh.

Diantara semua isolate yang diuji ternyata isolate LK4 dan LK 6 yang berasal dari limbah pabrik kertas mempunyai kemampuan menurunkan kadar sufat media yang tertinggi.

rawa pasang surut, rawa lebak dan pantai. Proyek Penelitian sumber Daya Lahan. Pusat Penelitian Tanah dan Agroklimat. Badan Litbang Pertanian. Departemen Pertanian.

Postgate, J.R. 1984. The Sulphate Reducing Bacteria. $2^{\text {nd }}$ ed. Cambridge University Press. New York.

Siagian, N., Enny Widyati, K. Azwir, Y. R. V. Sembiring, M. Andriyanto, 2015.

Reklamasi Lahan Eks Tambang

Batubara Melalui Penanaman Mucuna

bracteata Dan Karet (Hevea brasiliensis) Serta Aplikasi Bakteri Pereduksi Sulfat.

Laporan Penelitian. PPK Sei Putih.

Widyati, E. 2007. Pemanfaatan Bakteri Pereduksi Sulfat untuk Bioremediasi Tanah Bekas 
Vol.3, No.3. Desember 2016. (26) : 235- 238

Tambang Batubara. Biodiversitas, 4(8): 283-286. 